\title{
Câmbio de longo prazo do mil-réis: uma abordagem empírica referente às taxas contra a libra esterlina e o dólar (1795-1913) ${ }^{1}$
}

\author{
Heitor Pinto de Moura Filho*
}

\begin{abstract}
Resumo
Apresentam-se séries de taxas de câmbio nominais do mil-réis e do dólar frente à libra, e do mil-réis frente ao dólar. Para cada uma dessas relações, é construída uma série corrente, incluindo flutuações conjunturais, e outra de longo prazo, representando a tendência secular do câmbio. São discutidas as principais flutuações conjunturais combinadas do mil-réis e do dólar, e a vantagem do exame conjunto das oscilações e da tendência. $\mathrm{O}$ texto inclui quadros com as taxas cambiais anuais para as seis séries.
\end{abstract}

Palavras-chave: Câmbio; Dólar; Estados Unidos; Preços de escravos.

Desde Alfred Marshall, a distinção, teórica e a histórica, entre "curto prazo" e "longo prazo" sofre ao ser transposta para a realidade histórica. ${ }^{2}$ Neste trabalho sobre taxas cambiais do mil-réis ao longo de pouco mais de um século, propomos um entendimento puramente empírico do problema, que desconsidera a lógica da abstração, para amalgamar, numa mesma sequência temporal, o tempo histórico e o teórico: nosso longo prazo cambial passa a ser a média móvel para a qual as taxas retornam após flutuações “excepcionais”, isto é, aquelas fora desta média móvel.

Partimos com o objetivo inicial de estimar uma série temporal de taxas entre o mil-réis e o dólar que proporcionassem uma referência para estudos comparativos entre o Brasil e os Estados Unidos, nos oitocentos, o que, entretanto, nos levou à percepção da necessidade de separarmos os movimentos cambiais mais permanentes (estruturais,

\footnotetext{
${ }^{1}$ Versão anterior deste texto, Taxas cambiais do mil-réis contra o dólar (1795-1913), foi apresentada ao VII Congresso Brasileiro de História Econômica e $8^{a}$ Conferência Internacional de História de Empresas, Aracaju (SE), 2 a 5 de setembro de 2007. Agradeço os comentários subsequentes do professor Richard Graham.

* Economista e mestre em História Social pela Universidade Federal do Rio de Janeiro (UFRJ).

2 Empregando um conceito matemático, poderíamos dizer que o tempo teórico a que este "curto" e este "longo" se referem corre num eixo ortogonal ao tempo cronológico, histórico, pois depende da famigerada condição ceteris paribus, impossível de se combinar com a realidade histórica fora desta ortogonalidade abstrata. Traduzindo "ortogonal", podemos pensar que, de cada momento cronológico, parte uma linha "temporal" abstrata, levando do curto, ao médio e ao longo prazo, tudo sem sair do momento histórico original!
} 
dirão), que associaremos aqui à curva mais estável "de longo prazo", dos movimentos mais instáveis - conjunturais -, associados às flutuações que chamaremos de “correntes". Esta redefinição empírica dos conceitos marshalianos mostrou-se coerente com o histórico de crises e outras perturbações econômicas de menor vulto, inevitavelmente refletidas nas taxas cambiais. Pensamos, além do mais, que esta oposição entre a volatilidade conjuntural e uma regularidade subjacente (definida empiricamente, que seja) poderá ser útil para pesquisadores em história econômica evitarem as muitas armadilhas inerentes às comparações com intermediação cambial, já que das comparações dificilmente escapam, pois, como disse Richard Graham (1981), "toda história é comparativa".

\section{A comparação de valores em moedas diversas}

Primeiramente, exemplificamos a busca por comparações entre contextos referenciados a diferentes moedas, frequentemente mediadas por taxas cambiais, através da historiografia sobre escravidão e economias agro-exportadoras. Os estudos sobre escravidão no Brasil comparado aos de outros países focaram sobre aspectos qualitativos da instituição - por exemplo, Ciro F. Cardoso (1979), Richard Graham (1981) ou Carl Degler (1986) - ou quantitativos, mas não monetários - por exemplo, Stuart Schwartz (1985). Por seu lado, os estudos demográficos buscaram, através da análise dos indicadores de nupcialidade, fecundidade e mortalidade, bem como das estruturas quantitativas por nacionalidade, sexo, idade ou atividade, entre outros aspectos, uma compreensão comparativa das economias escravistas nas Américas, que passa ao largo de problemas cambiais. Para complementar tais abordagens, no entanto, tornam-se importantes as comparações diretas de dados monetários, como preços de escravos ou custos de sua manutenção no Brasil e nos Estados Unidos. A transformação cambial também é claramente relevante para o estudo comparativo dos setores primários de cada país: açúcar, tabaco, algodão e café, no Brasil e as mesmas commodities, sem o café, nos Estados Unidos.

Antes de tratar da construção de uma série secular para o valor do dólar em milréis, gostaríamos de enfatizar que a mera transformação de preços em mil-réis para preços em dólares, ou vice-versa, não esgota, de modo algum, o entendimento comparativo de valores de escravos ou de commodities, num e noutro país. Para analisarmos adequadamente o significado desses preços, torna-se necessário incorporar 
ao raciocínio os referenciais próprios à escravidão e à produção das mercadorias, entre os quais os respectivos custos de manutenção de um escravo, as receitas esperadas por seu trabalho em cada país, além dos índices de preços das mercadorias produzidas ou dos bens de capital. Essa discussão associa-se também à polêmica em torno da produtividade relativa de escravos e de trabalhadores livres, iniciada nos EUA durante os anos $1950 .^{3} \mathrm{Na}$ medida em que ambas as economias se inseriam no contexto financeiro mundial, tais estudos comparativos poderão ter ramificações vinculadas a temas bastante atuais na historiografia econômica, que analisam a globalização no século XIX, tais como os efeitos da distância, de preços relativos e de tarifas alfandegárias sobre o desenvolvimento ou ainda a importância do contágio de crises nos movimentos internacionais de capitais.

Além disso, também é essencial lembrar que a transformação dos preços internos de um país por taxas de câmbio traz dificuldades próprias para a análise historiográfica, já que tais taxas são determinadas por combinações flutuantes de efeitos, que se sobrepõem ao contexto específico de cada setor estudado. ${ }^{4}$ Tais efeitos derivam do conjunto de operações do comércio internacional, das operações bancárias com câmbio, dos contextos nacionais de financiamento ao setor público, além dos movimentos internacionais de capitais. E não podemos esquecer, é claro, os movimentos mais "emocionais" que se somam a esses econômicos, nos momentos de crises políticas. Além de sua tendência secular, as relações comerciais demonstram oscilações intra-anuais específicas aos movimentos conjunturais de exportação e importação. ${ }^{5}$ As operações bancárias, embora estruturalmente associadas às relações comerciais, impõem uma dinâmica própria ao mercado de câmbio - tradicionalmente contrabalançando as demandas e ofertas de moeda estrangeira do comércio, mas também introduzindo, em épocas críticas, como ocorreu nos primeiros anos do período

\footnotetext{
${ }^{3}$ Para uma apreciação dessa polêmica, ver H. Aitken (1971), M. Thorton (1994) e R. Fogel (2003). Para uma avaliação econômica da rentabilidade da escravidão no Brasil, ver R. Slenes (1976), P. Mello (1977), L. Correa do Lago (1978), Mello \& Slenes (1980) e F. Versiani (1994).

${ }^{4}$ Até hoje a teoria econômica se desvela em obter modelos para explicar os níveis e as oscilações cambiais, sem que um modelo sobressaia frente aos demais. Enquanto modelos alicerçados sobre as relações propostas pela teoria econômica apresentam certo sucesso na explicação "de longo prazo", técnicas totalmente empíricas, como a análise de flutuações de preço através de métodos gráficos, a chamada "análise técnica" dos analistas bursáteis, se destacam na previsão de curtíssimo prazo, até um mês. Para uma resenha interessante dos modelos de explicação cambial, ver MacDonald \& Taylor (1992).

${ }^{5}$ Como exemplo desse acúmulo de efeitos, podemos citar E.Cardoso, em "Exchange rates in XIX Century Brazil: An Econometric Model" no Journal of Development Studies (1983), que considera que "[...] a paridade de poder de compra não é suficiente para explicar o comportamento da taxa de câmbio, que respondia claramente a receita das exportações de café." (CARDOSO apud GOLDSMITH, 1986, p.62).
} 
republicano, seu componente, independente, de especulação. As movimentações cambiais do governo, ao receber e amortizar empréstimos e manter o serviço da dívida, influem significativamente nas cotações do mercado, ainda mais quando essas necessidades foram sistematicamente antecipadas pelos bancos, conhecedores dos compromissos do governo brasileiro. ${ }^{6}$ Em sua história da economia brasileira, de 1935 , J. Normano expunha os conhecidos conflitos de interesses em torno do câmbio:

Os produtores de artigos de exportação inclinam-se à inflação de papel no país, ao passo que os importadores advogam a necessidade de uma moeda estável. O capitalista estrangeiro alia-se aos propagandistas da moeda estável e o credor estrangeiro usa a sua influência no mesmo sentido. (NORMANDO, 1975, p.175 -176)

E ainda, a percepção de risco da dívida soberana afeta os movimentos capitais, tendo, em consequência, repercussões sobre o mercado de câmbio. ${ }^{7}$ Ao fazermos uso de taxas de câmbio em análises historiográficas comparativas, estaremos embutindo em nossas comparações, além de tais fatores especulativos, as circunstâncias próprias a cada país: com relação à economia norte-americana, as flutuações cambiais decorrente de períodos de guerra, do funcionamento do padrão bimetálico e, em seguida, do padrão ouro, bem como das crises bancárias enfrentada pelos Estados Unidos; e, no caso brasileiro, as sucessivas depreciações monetárias, relacionadas a crises de confiança bancária, a crises de financiamento do setor público e à proteção financeira dos exportadores de café num ambiente inflacionário. Por outro lado, os marcos institucionais do fim do tráfico e da abolição da escravidão, que ocorreram em épocas distintas, num e noutro país, tiveram sua influência nos preços de escravos em períodos defasados. Assim, a análise comparativa dos preços "americanizados" ou “abrasileirados" deverá considerar a sobreposição desses diversos fatores e momentos

\footnotetext{
${ }^{6}$ Maria Bárbara Levy (1977, p.279-304), descreveu em detalhes as operações especulativas com o câmbio, desenvolvidas pelos bancos estrangeiros logo após a febre de especulação com ações do Encilhamento. Além de gerar movimentações diárias no mercado cambial até quatro vezes maiores que o usual, envolviam infrações à legislação em vigor, ao não identificar os investidores. "As agências bancárias no Rio de Janeiro mantinham relações com suas caixas matrizes no estrangeiro que, por sua vez, conheciam perfeitamente nossas necessidades. [...] conheciam qual o curso dos nossos títulos no exterior, estudavam e fixavam quais eram os nossos compromissos e as épocas de efetuar os pagamentos, além de calcularem, a toda hora, a soma de recursos que o Brasil possuía nas mãos dos seus banqueiros e as encomendas feitas no exterior." (LEVY, 1977, p.213)

${ }^{7}$ Cid Botelho Jr. comenta a repercussão indireta no Brasil da crise argentina de 1890, afirmando que "a fragilidade dos modelos econométricos, para estabelecerem os determinantes da desvalorização cambial, talvez esteja relacionada ao fato de que há muitas influências difíceis de serem captadas, como é o caso da manipulação da taxa de câmbio por agentes financeiros e das expectativas políticas que apresentaram-se extremamente voláteis na conturbada primeira década republicana." (BOTELHO Jr., 2003, p.18)
} 
institucionais. No caso dos estudos historiográficos das mercadorias agrícolas, surgirão dificuldades contextuais análogas.

\section{As muitas taxas cambiais}

Mencionados esses caveats, vamos estabelecer nossas séries. Desde a chegada da corte portuguesa até a Segunda Guerra Mundial, nosso comércio exterior e as transações financeiras governamentais e de investimentos foram referenciadas fundamentalmente ao mercado bancário londrino e, portanto, à libra esterlina. As praças que se seguiam em volume de relacionamento eram as francesas e belgas, em francos, e Hamburgo, em marcos, conforme podemos aferir do quadro abaixo, que mostra o percentual do valor em mil-réis dos saques contra Londres correspondente ao valor, também em mil-réis, dos saques contra essas outras praças. Não dispomos das mesmas estatísticas com relação aos Estados Unidos para todos esses períodos, mas nos quatro anos logo anteriores à Primeira Guerra, esse percentual foi de somente 1,4\% para os saques contra Nova Iorque.

\begin{tabular}{lccc}
\hline & França & Hamburgo & Nova Iorque \\
\hline 1876 a 1880 & $73,5 \%$ & $6,4 \%$ & $\mathrm{n} / \mathrm{d}$ \\
1882 a $1888($ sem 85$)$ & $40,8 \%$ & $2,6 \%$ & $\mathrm{n} / \mathrm{d}$ \\
1909 a 1913 & $15,7 \%$ & $4,2 \%$ & $1,4 \%$ \\
\hline
\end{tabular}

Quadro 1: Percentual do valor em mil-réis dos saques contra Londres correspondente ao valor em mil-réis dos saques contra outras praças selecionadas Fonte: Jornal do Commercio, Retrospecto Commercial, diversos anos. Nossa elaboração.

Faremos uma pequena digressão sobre a representatividade das taxas cambiais publicadas, para insistir no fato de que as estatísticas não apresentam precisão semelhante, nem correspondem necessariamente ao rótulo que as intitula. Podemos distinguir diversos tipos de informação sobre taxas de câmbio quanto à precisão dos dados e método de registro:

a) um primeiro, o mais detalhado e preciso, de taxas de negócios individuais, realizados em bolsas ou entre bancos e seus clientes;

b) um segundo tipo seria um relatório - quinzenal, no caso da Junta de Corretores do Rio de Janeiro - sobre um conjunto de tais transações individuais, negociadas ou registradas em bolsa, produzido pela própria instituição; 
c) um terceiro tipo, mais comum, é a publicação de taxas mínimas, máximas e/ou médias, supostamente representativas de operações realizadas durante um período qualquer, em certo mercado, usualmente encontrado na imprensa geral ou especializada;

d) um quarto tipo de informação são taxas implícitas às transações incorporadas em agregados contábeis, tais como estatísticas de comércio exterior ou negócios registrados em demonstrações financeiras de um banco, obtidas pela divisão de um valor total em moeda nacional, pelo valor equivalente em divisa. $\mathrm{O}$ primeiro tipo de dado oferece informações essenciais à classificação correta da taxa cambial no que toca ao prazo da transação e ao nível de crédito do sacado, informações necessárias para sua correta homogeneização numa série temporal. Boletins diários de operações em bolsa vêm em seguida, em termos de precisão, embora seu formato, regularidade e abrangência possam sofrer alterações que dificultem a compilação de séries uniformes. Taxas cambiais publicadas na imprensa podem provir de tais boletins ou ser simplesmente uma reunião, sem metodologia regular, de negócios informados por agentes do mercado. Podem não distinguir diversidade de prazos, de sacados, nem informarem os montantes totais negociados em cada categoria, além de haver incerteza sobre a sistematicidade do método de coleta. Nas palavras de Davis e Hugues, comentando esta diferença:

The data, then, are actual dollar prices paid by an American firm for prime sterling exchange at the relevant maturities. Exchange rates arising from actual transactions are, in important ways, superior to averages of advertized rates in the commercial press. (DAVIS; HUGUES, 1960, p.53)

O Retrospecto Commercial do Jornal do Commercio do Rio de Janeiro pode ser considerado uma exceção aos descuidos da imprensa com detalhes técnicos, por se tratar de publicação especializada e ciosa de oferecer informações relevantes a um público profissional. Como exemplo do cuidado de seus editores, recolhemos o seguinte comentário: "As taxas extremas do câmbio sobre Londres em 1880 foram de 197/8 e 24 d. Esta última taxa foi excepcional e para uma só transação no mês de setembro. Conservamo-la todavia porque o Boletim da junta de corretores, documento oficial, a consignou". Noutro ano, aponta as falhas na cobertura do Boletim da Junta de Corretores 
A tabela de saques efetuados seria de valioso auxílio para o estudo [das remessas para fora da praça], se ela manifestasse a realidade dos fatos; infelizmente essa tabela, posto que [apesar de] organizada com dados oficiais, os Boletins quinzenais da junta dos corretores, não inspira a necessária confiança, pois é sabido por todos que grande número de transações importantes em cambiais não chega ao conhecimento da junta. (1882, p.12)

As taxas implícitas, por outro lado, nos garantem a mesma precisão e abrangência de suas fontes contábeis. No caso das estatísticas do comércio exterior e mesmo de contabilidades bancárias, essas taxas sofrem, no entanto, pela mistura de transações de diversos prazos e qualidade de sacado, o que traz problemas sérios para seu uso em cálculos econômicos mais refinados, embora afetem em grau bem menor médias abrangentes, tais como taxas representativas dos negócios de um ano inteiro. No caso das estatísticas retrospectivas sobre o comércio exterior brasileiro publicadas pelo IBGE (IBGE, 1990, p.568-571), os organizadores deixam claro que as taxas de câmbio implicitas são calculadas como o quociente entre os valores em mil-réis e aqueles em libras. (IBGE, 1990, nota 1, p.569)

Ao depararmo-nos com taxas referenciadas a um período mais longo, torna-se importante, embora nem sempre possível, sabermos como essas taxas foram calculadas: como médias de todas as transações consideradas individualmente ou como média de médias mensais ou semanais; e ainda, se foram médias aritméticas de taxas soltas ou se foram obtidas pela divisão de valores totais numa moeda e noutra etc. As taxas individuais costumam ser apresentadas reunidas por dia, mês ou ano de transação, com indicação dos valores mínimo, médio e máximo, obtidos durante o período em questão. É comum, ao se obter médias diárias, mensais ou anuais de taxas individuais, não se levar em conta os valores negociados a cada taxa, sendo calculada, em geral, uma média simples de todas as taxas informadas, sem atenção para o valor de cada transação. Médias anuais são comumente calculadas como uma média aritmética das médias diárias ou até mensais, não refletindo necessariamente as distorções intra-anuais grande volume negociado a taxas de pico ou grande volume concentrado numa parte do ano, por exemplo. As taxas implícitas, inversamente, refletem, por definiç̧ão, o valor médio do conjunto de transações, pois são obtidas pela divisão dos valores totais negociados.

Além das discrepâncias ocasionadas pela diversidade na amplitude do período sobre o qual se recolhem os valores das taxas de câmbio, nos métodos de agregação e de representação utilizados e na abrangência de negócios atingida na sua compilação, é 
essencial termos em vista que sempre houve grande variedade nas taxas de câmbio sincrônicas em decorrência de dois importantes fatores negociais: o crédito atribuído ao título e os juros embutidos na taxa conforme o prazo para seu saque. Tal variedade existia em qualquer tipo de conjuntura e se traduzia em preços relativos, isto é, taxas cambiais, diferenciadas, refletindo diferentes compromissos contratuais ou percepções de riscos distintas. Cada taxa individual reflete essa variedade sincrônica, podendo incorporar ou não parte dos custos necessários à transação, no caso, o custo de remessa da cambial à praça sacada e das comissões envolvidas no seu recebimento. As taxas implícitas, ao contrário, resumem num único valor a média das transações individuais agregadas em seu cômputo, incorporando, assim, uma distribuição flutuante de tipos de transação (relativamente à mencionada percepção de crédito e ao prazo do negócio). Analogamente, taxas máximas, mínimas ou médias indicativas do mercado em certo período raramente distinguem riscos de crédito diferenciados, embora possam estar homogeneizadas quanto ao prazo - as taxas publicadas pelo Retrospecto Commercial, por exemplo, mencionam, para cada praça, o prazo usual dos saques e se o tomador era banco ou particular.

Para exemplificar essas diferenças sincrônicas, vejamos os preços relativos representados por descontos - existentes na praça do Rio de Janeiro entre tipos de contrato, segundo o risco atribuído à liquidação efetiva do negócio, com a entrega de moeda estrangeira. Distinguiam-se tipos de cambiais conforme sua combinação de emissor e sacado: particular sobre banco ou banqueiro, particular sobre particular, banco sobre banqueiro e banco sobre caixa matriz. Os dois primeiros tipos, conhecidos como "letras aprovadas" ou coffee bills, ofereciam maiores garantias, já que estavam atrelados a mercadorias específicas, com nome de navio e data de embarque. O preço do terceiro tipo, as "letras bancárias diretas", de um banco brasileiro sobre outro no exterior, era cerca de $0,6 \%$ menor que o das letras aprovadas. $\mathrm{O}$ último tipo, saques de filiais contra matrizes do mesmo banco, era considerado como ainda menos seguro, recebendo preço com cerca de 1,2\% de desconto (LEVY, 1977, p.289-291). Cumulativamente a esses descontos por risco, as cambiais brasileiras embutiam juros entre $4 \%$ a $6 \%$, conforme o prazo de liquidação, o que representava diferencial de cerca de $1 \%$ a 1,5\% entre letras à vista e ao prazo de 90 dias. $^{8}$

\footnotetext{
${ }^{8}$ J. T. Klovland historia o funcionamento do mercado cambial de Oslo no início do século XIX, onde eram negociadas letras de câmbio à vista e a 1, 2 e 3 meses de prazo, sobre Londres e outras capitais
} 
Essa variedade de taxas na época de sua negociação e na forma como se apresentam nas fontes torna-se relevante para nosso atual estudo na medida em que nos informa sobre a precisão que poderemos atribuir aos valores compilados. Assim, ao tratarmos com médias anuais relativas a todo tipo de contrato, além do mais sem indicação de sua volatilidade no período, devemos abandonar, no caso da taxa milréis/libra, qualquer tentativa de normalizar as taxas cambiais pelo desconto dos juros embutidos ou pelo tipo de contrato. As taxas dólar/libra empregadas já embutem esta normalização, dando às nossas séries mil-réis/dólar um grau de imprecisão semelhante à do mil-réis/libra. Como regra geral, podemos considerar que, nas épocas mais estáveis, estamos lidando com uma margem de erro entre $1 \%$ e $3 \%$ correspondente a possíveis diferenciais de juros mais descontos por nível de crédito.

\title{
Fontes utilizadas
}

Além das dificuldades conceituais e de método mencionadas acima, devemos lembrar a relutância do comércio em abrir ao público os detalhes de suas operações, numa época ainda distante de obrigações regulatórias, fato que distorcia as informações publicadas, seja pela omissão de transações, seja pelo deslocamento no tempo de sua data de referência. Quanto a esses aspectos, o comentário abaixo, do Retrospecto Commercial, é esclarecedor:

\begin{abstract}
A compra do café, a negociação dos cambiais e o fretamento dos navios são três operações que se fazem quase simultaneamente, que estão em recíproca dependência; a divulgação antecipada de uma delas pode dificultar muito, senão impossibilitar, a realização das outras. Compreendemos tambem a repugnância de muitos comerciantes pela cotação pública de suas firmas, isto é, pela análise e apreciação diária de sua posição. Desta repugância resultou não se verificar oficialmente o curso dos câmbios e não ter a junta dos corretores base alguma para sequer passar uma certidão, documento muitas vezes requerido por negociantes e reclamado pelas estações públicas. Nada, entretanto, impede, em nossa opinião, que ultimadas as transações de câmbio e descontos, os corretores publiquem na Bolsa as taxas a que as realizaram. $(1876$, p.12)
\end{abstract}

Apesar dessas omissões, sempre houve registros de taxas de câmbio. A prolongada importância do movimento cambial dirigido a Londres fez com que sejam facilmente encontradas fontes para o câmbio do mil-réis frente à libra, o que não é o caso, contudo, para as taxas de câmbio entre o mil-réis e o dólar, principalmente no normalizando-se todas as taxas como equivalente à vista (KLOVLAND, 2004, p.289-90). 
período anterior a 1870. Para as taxas contra a libra, uma série frequentemente utilizada é a das taxas de câmbio implícitas no comércio exterior do Brasil, publicadas pelo IBGE na série sobre estatísticas retrospectivas (FRANCO, 1990, p.568-571). ${ }^{9}$ No caso do câmbio do mil-réis frente ao dólar norte-americano, o Retrospecto Commercial publica cotações, mas somente de 1876 a 1920. A única série mais longa, de nosso conhecimento, é aquela fornecida por J. Duncan, de médias anuais, entre 1821 e 1930, em apêndice ao seu estudo das ferrovias brasileiras J. S. Duncan (1932). ${ }^{10}$

Um método preciso para obter taxas mil-réis/dólares seria recolher, seja no Brasil, seja nos Estados Unidos, fontes para a construção de uma série própria, baseada em transações individuais ou nas estatísticas do comércio bilateral. Adotamos um caminho alternativo, mais imediato, que é transformar uma série conhecida do câmbio mil-réis/libra, por uma série de taxas dólares/libra. A existência de dificuldades metodológicas nos levaram, portanto, a optar pelo cálculo das taxas mil-réis/dólar pela divisão da série mil-réis/libra implícitas no comércio exterior do Brasil, pela série dólar/libra produzida por Lawrence Officer, obtendo uma série mil-réis/dólar minimamente homogênea ao longo de 120 anos. ${ }^{11}$

Vale lembrar que desejamos estabelecer uma série de taxas de câmbio "nominais", não entrando em considerações sobre a evolução do poder de compra das moedas, em seus próprios países ou em relação a outras moedas. ${ }^{12}$

Como fonte para a série mil-réis/libra, empregamos a série de taxas de câmbio implícitas no comércio exterior, de 1821 a 1914, mencionada acima. Complementamos esta série, no período de 1808 a 1822, com dados de Calógeras (1960), adicionando algumas referências anteriores, obtidas em Simonsen (1969), para chegar a um período

\footnotetext{
${ }^{9}$ Nozoe et al. (2004) comentam as diversas séries estatísticas cambiais publicadas. No capítulo sobre "Setor externo" do volume do IBGE sobre Estatísticas Históricas do Brasil (FRANCO, 1990), são reproduzidas as taxas de câmbio mensais publicadas pelo Retrospecto Commercial (1876-1920), complementadas por outras fontes, com referência ao período de 1870 a 1930.

${ }^{10}$ Agradeço ao Professor Richard Graham esta referência. Vale mencionar que esta série de Duncan se distancia numericamente de nossa série corrente durante os anos da Guerra Civil e seguintes, quando a série de L. Officer, que empregamos, também se distancia dos valores referenciais para incorporar as acentuadas flutuações conjunturais.

${ }^{11}$ Klovland (2004) segue procedimento semelhante, calculando a taxa coroa/dólar a partir da série coroa/libra estabelecida por ele e a série dólar/libra oferecida por Officer, já que quotações diretas entre a coroa norueguesa e o dólar só foram apareceram sistematicamente a partir de 1914. Nozoe et al. (2004) consideram a série de taxas implícitas publicada pelo IBGE como uma das melhores fontes para o câmbio mil-réis/libra. Graham (2005) lamenta a falta de dados sobre o câmbio de Portugal antes de 1808.

${ }^{12}$ Richard Graham (2005), ao buscar um referencial inter-temporal para o poder de compra, lista algumas dificuldades em se utilizar a transformação cambial: o poder de compra da moeda estrangeira flutua, até no próprio país emissor, há fortes discrepâncias sincrônicas nas taxas cambiais entre portos de diferentes regiões brasileiras e, além disso, não há séries cambiais publicadas para o período colonial brasileiro.
} 
semelhante àquele disponível para o dólar. Para a série dólar/libra esterlina, fizemos uso de dados produzidos por duas fontes: L. Officer (2002), que produziu uma série homogenizada quanto aos prazos e que incorpora maior flutuação conjuntural, e T. Doan \& T. Dick (2001), cuja série reflete os valores referenciais do padrão cambial metálico preferencialmente aos ágios e deságios conjunturais. A série mil-réis por dólar "corrente" foi obtida pela divisão da série mil-réis/libra pela série dólar/libra.

Para cada uma dessas séries, montamos, por médias móveis sucessivas, sobre dados que excluíam os períodos de maior volatilidade, nossa série de "taxas de longo prazo", correspondentes a uma tendência subjacente, da qual se afastam as taxas em momentos de crise. Para a relação dólar/libra de longo prazo, empregamos a série montada por Thomas Doan, que já reflete esta estabilidade. Enviaremos nossas séries, corrente e de longo prazo, para as três combinações de moedas, aos interessados.

\section{As séries básicas: dólar por libra e mil-réis por libra}

Nas figuras seguintes, apresentamos as séries "corrente" e "de longo prazo", para as duas relações cambiais, dólar/libra e mil-réis/libra.

A série "de longo prazo" sugere pelo menos três momentos tendenciais para o câmbio do dólar frente à libra: a) uma fase de discreta valorização, de 1795 até por volta de 1810 - a cerca de 0,2\% ao ano -, b) uma fase de desvalorização ligeiramente mais acentuada, nas duas décadas e meia seguintes, até 1835 - a cerca de 0,5\% ao ano -; e c) um longo período de estabilidade estrutural, sustentada pelo padrão bimetálico e, em seguida, pelo padrão ouro, que se manteve até meados do século XX.

Sobrepusemos aos gráficos anotações dos principais contextos conjunturais relativos ao câmbio dólar/libra: as guerras napoleônicas, combinadas com a crise e guerra contra a Inglaterra em 1812-13, a crise bancária de 1837, a Guerra Civil e o período de crise econômica subsequente, durante a década de 1870. Como medida relativa do tamanho da perturbação cambial, mostramos logo abaixo a diferença percentual entre nossas taxas corrente e de longo prazo, calculadas anualmente. 


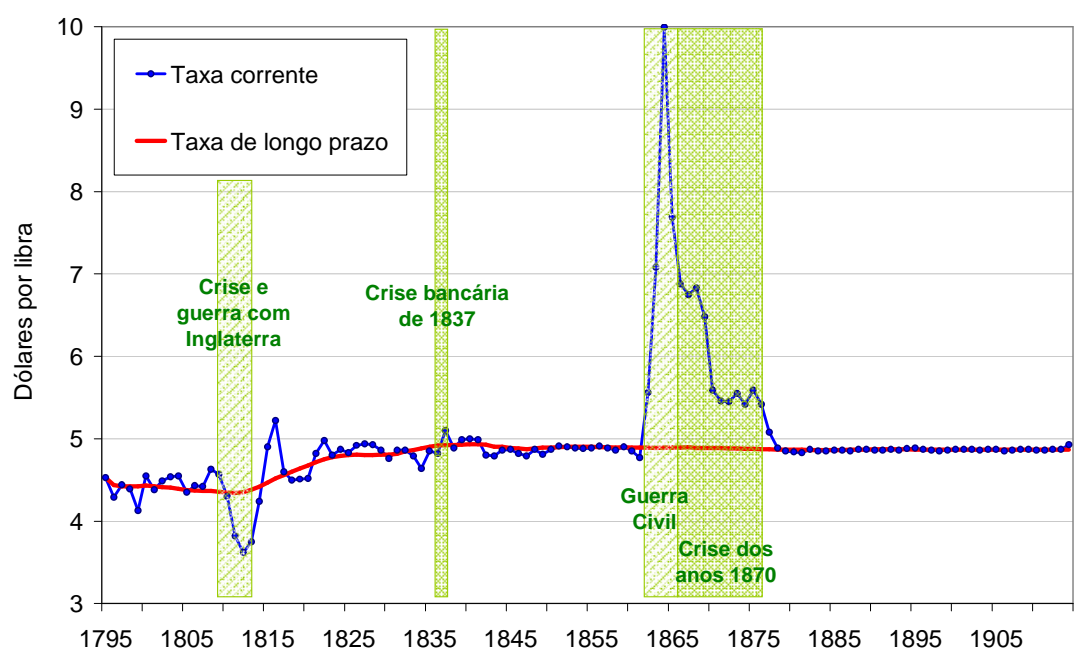

Gráfico 1: Evolução das relações cambiais dólar/libra: taxas correntes e de longo prazo (1795-1913)

Fonte: Dados originais e elaboração conforme descritas no texto.

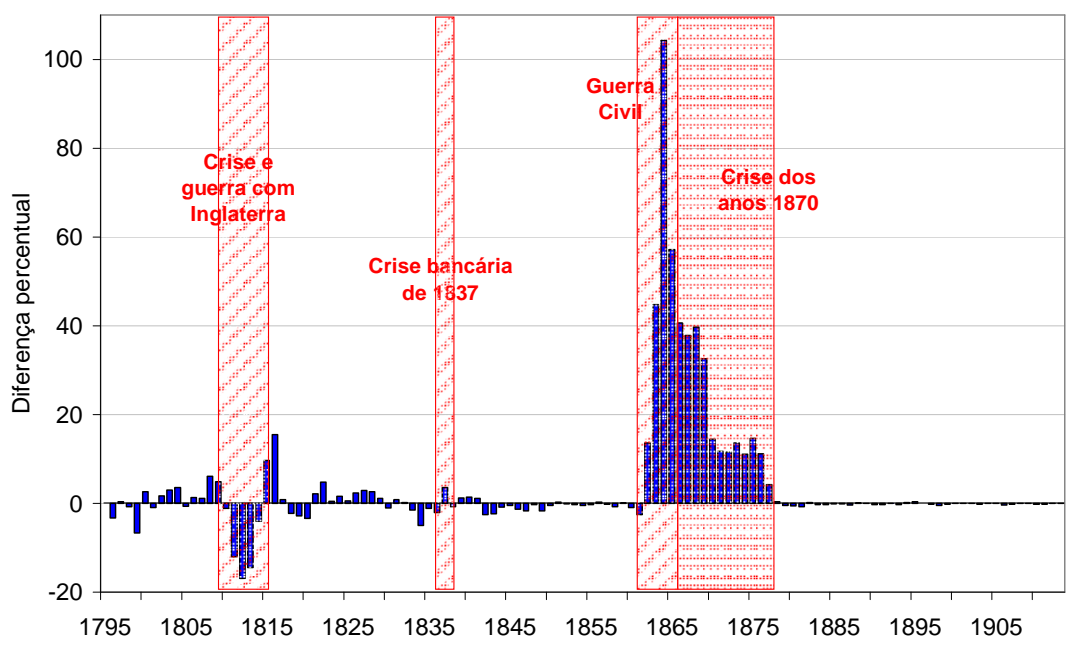

Gráfico 2: Afastamento percentual das taxas correntes com relação às taxas de longo prazo, ano a ano (dólar por libra) Fonte: Séries do quadro anterior.

Seguem os mesmos gráficos para as séries do mil-réis contra a libra. Ao contrário do dólar, o mil-réis apresentou uma clara tendência secular de desvalorização, na qual podemos distinguir três fases, de cerca de três décadas cada. Numa primeira, aproximadamente da chegada da corte até o início do Segundo Reinado - de 1810 a 1844 -, a taxa de longo prazo do mil-réis contra a libra se desvaloriza num ritmo regular, a cerca de 2,9\% ao ano. Daí até o início da década de 1870 há um período de grande estabilidade, durante o qual o câmbio se desvaloriza a somente $0,3 \%$ ao ano. Talvez surpreendendo o entendimento tradicional, na fase seguinte - de maior 
turbulência conjuntural - até 1905, o mil-réis se desvaloriza tendencialmente a 1,4\% ao ano, variação bastante inferior à da tendência durante a pré-Independência e o Primeiro Reinado.

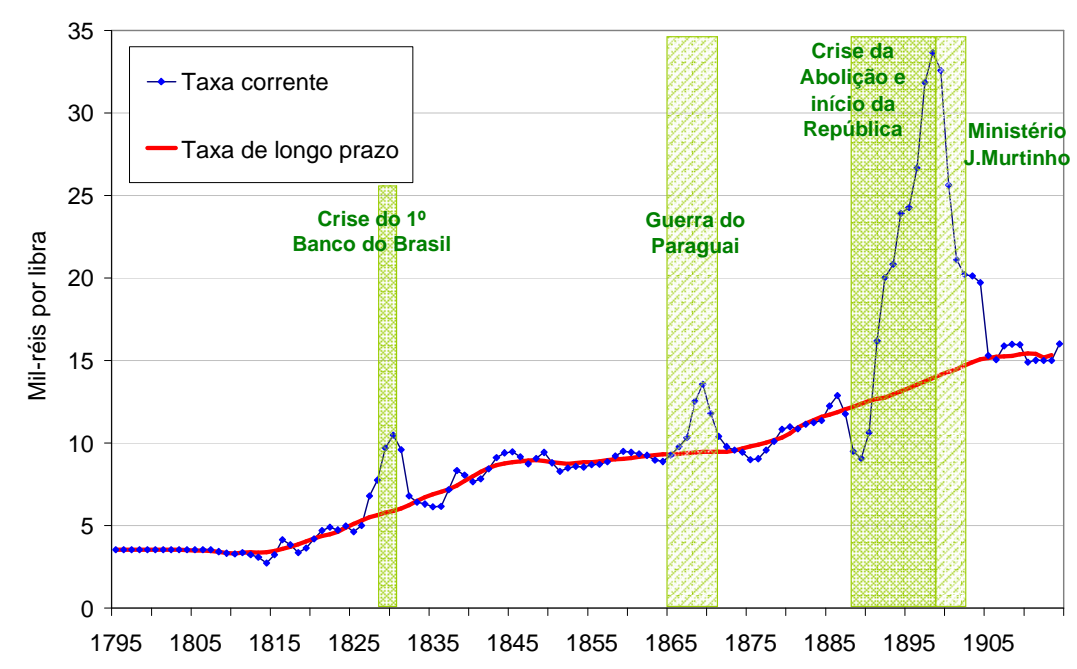

Gráfico 3: Evolução das relações cambiais mil-réis/libra:

taxas correntes e de longo prazo (1795-1913)

Fonte: Dados originais e elaboração conforme descritos no texto.

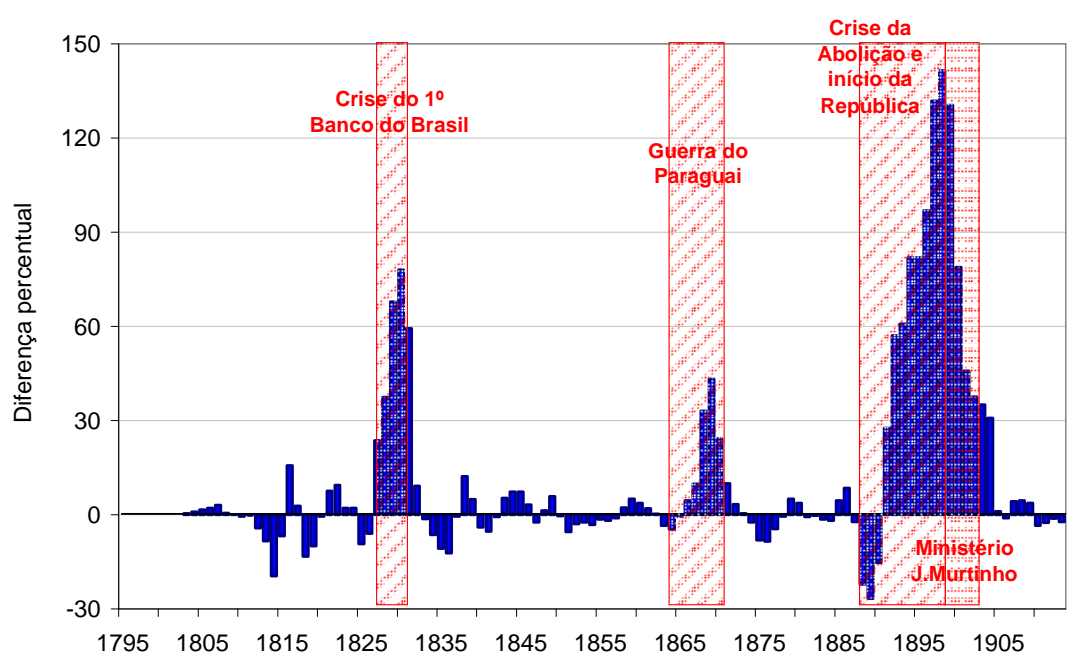

Gráfico 4: Afastamento percentual das taxas correntes com relação às taxas de longo prazo, ano a ano (mil-réis por libra) Fonte: Séries do quadro anterior.

No caso das relações cambiais do Brasil com a Inglaterra, as flutuações mais fortes, sempre medidas pelo afastamento das taxas correntes das de longo prazo, corresponderam aos períodos da crise em torno da liquidação do Primeiro Banco do Brasil - de 1827 a 1830 -, e da Guerra do Paraguai combinada com a quebra da Casa Souto - de 1864 a 1870 -, como também a década de crise iniciada com a Abolição, que 
se estendeu até a recuperação encaminhada por Joaquim Murtinho. Embora tenham afetado os mercados bancários e financeiros, além de provocarem falências em muitos setores, outras crises, em 1857 - Souza Franco -, 1875 - Mauá - e 1884 - depressão -, não tiveram o mesmo impacto sobre as médias anuais do câmbio como os três períodos mencionados. ${ }^{13}$ Confundindo-se com as crises brasileiras da Abolição, Encilhamento e insurreições militares do início da República, o default da dívida argentina em 1890 e a consequiente falência da Casa Baring Brothers foram apontados por vários estudiosos como dando origem ao primeiro caso de contágio por crise financeira na América Latina (TRINER, 2001; MITCHENER \& WEIDENMIER, 2006). Até que ponto esse possível contágio efetivamente se sobrepôs à crise brasileira? Até que ponto teria ampliado sua intensidade ou esticado sua duração? Ficamos aqui com a constatação de que, entre o momento referencial anterior à crise, que associaremos à média do triênio 1883/85, e o ano de maior desvalorização - 1898 -, nossa taxa corrente do mil-réis contra a libra se desvalorizou em $190 \%$, atingindo, neste pico, $142 \%$ da valor da taxa de longo prazo. No entanto, a sua revalorização, desse pico de 1898 até o momento referencial pós-crise, que consideraremos como a média do triênio 1905/07, precisou de um ganho um pouco menor para voltar a se igualar à taxa de longo prazo, já que a taxa no pico de desvalorização correspondia a somente $121 \%$ da taxa de longo prazo em vigor no momento pós-crise. Isto, é claro, foi consequência da desvalorização secular ocorrida em nossa taxa de longo prazo, do momento anterior ao momento posterior à crise, em $31 \%$, ou a quase $1 \%$ ao ano, durante estes 28 anos.

Verificamos, assim, que o passado cambial brasileiro, à exceção do período da Guerra Civil americana, teve picos de oscilação bem superiores aos norte-americanos. Enquanto nos Estados Unidos somente houve afastamentos superiores a $20 \%$ relativamente à taxa de longo prazo, no período da Guerra Civil e do seu desenlace, com depreciação de $100 \%$, no Brasil tivemos três momentos de depreciação cambial forte, no final da década de 1820 - quase $80 \%$-, durante a Guerra do Paraguai - pouco mais de $40 \%$ - e na crise do início da República - $140 \%$.

\section{As séries mil-réis por dólar}

Podemos calcular, agora, as séries de taxas de câmbio do mil-réis contra o dólar, obtidas por divisão das taxas mil-réis/libra pelas taxas dólar/libra.

\footnotetext{
${ }^{13}$ Ver M. B. Levy (1977). Sobre as crises de 1857 e 1864, ver A. Villela (1999); sobre a Guerra do Paraguai e sobre os bancos, ver C. G. Guimarães $(1999 ; 2007 ; 2009)$.
} 
Percebemos claramente a semelhança dessa evolução com a do mil-réis por libra, já que o dólar se manteve constante frente à libra durante boa parte do século. Os três principais momentos em que a taxa corrente fica abaixo da taxa de longo prazo marcam uma apreciação do mil-réis frente ao dólar: nas décadas de 1860 e 70, pela depreciação do dólar a partir da Guerra Civil, e na década de 1880, pela valorização do próprio mil-réis frente à libra.

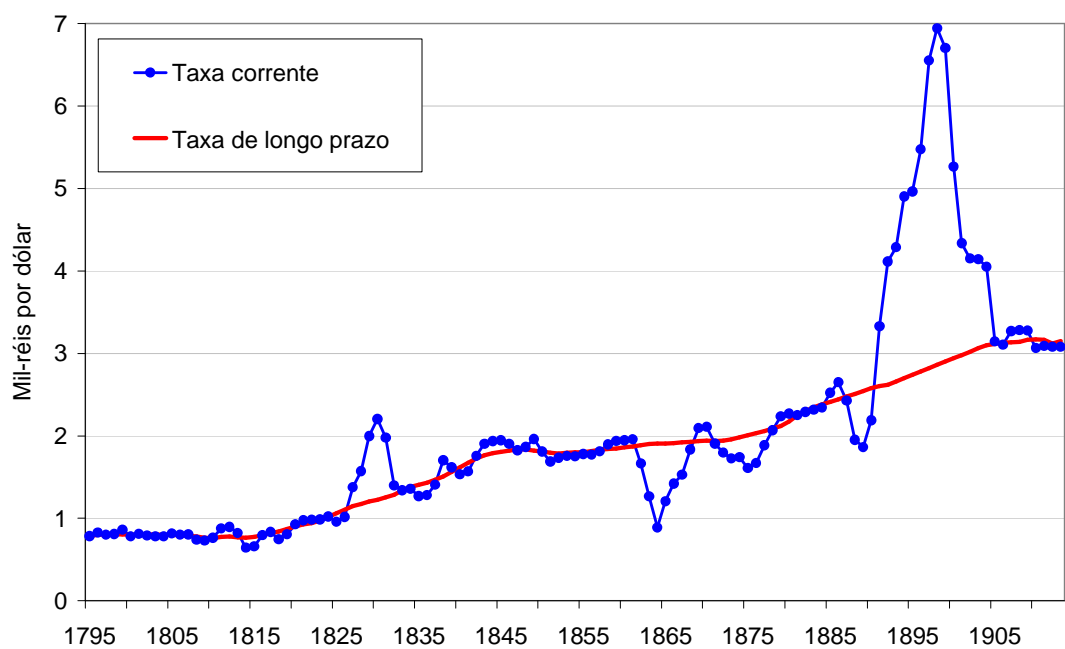

Gráfico 5: Evolução das relações cambiais mil-réis por dólar: taxas correntes e de longo prazo (1795-1913)

Fonte: Dados originais e elaboração conforme descritas no texto.

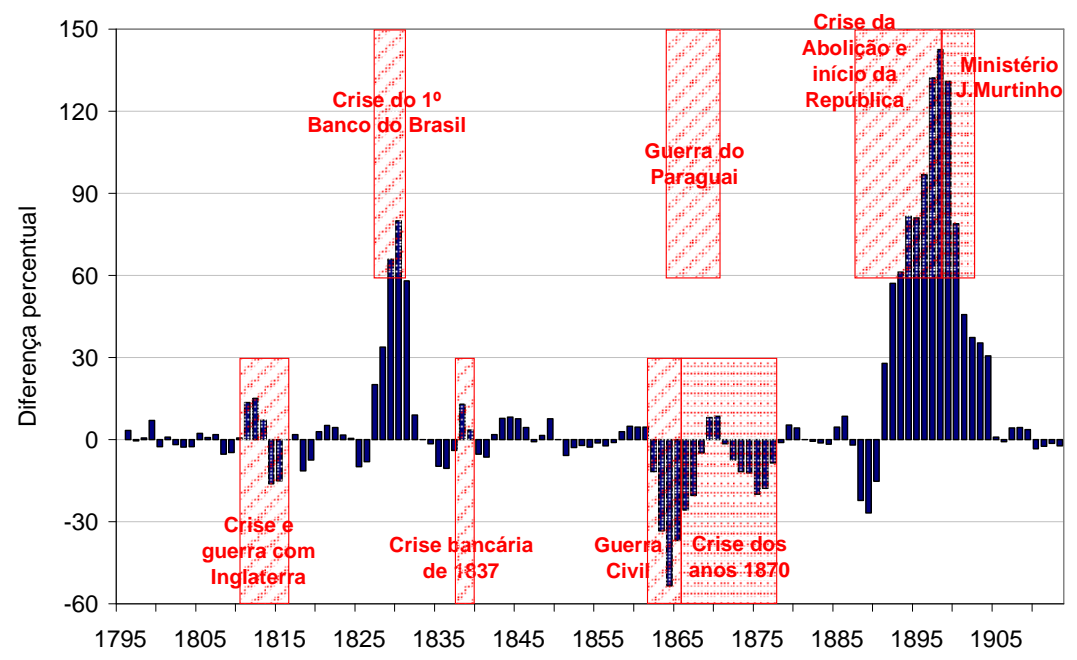

Gráfico 6: Afastamentos percentuais das taxas correntes com relação às taxas de longo prazo (mil-réis por dólar)

Fonte: Séries do quadro anterior. 
$\mathrm{Na}$ figura acima, apresentamos os afastamentos percentuais das taxas correntes mil-réis por dólar com relação às taxas de longo prazo. Anotamos simultaneamente os períodos de flutuação cambial no Brasil e nos Estados Unidos. Diferenças positivas indicam períodos de desvalorização relativa do mil-réis, enquanto inversamente as diferenças negativas indicam desvalorização relativa do dólar. A maioria dos períodos de flutuações excepcionais em algum dos países ocorreu em época de estabilidade no outro. Exceções importantes são as quase duas décadas da Guerra Civil norte-americana e da recuperação econômica subsequente, que coincidiu com a Guerra do Paraguai e as crises bancárias de 1860 e 70, o que gerou uma dinâmica diferenciada do câmbio bilateral, conforme comentamos a seguir.

Nos quinze anos que se seguiram ao início da Guerra Civil, durante os quais a moeda norte-americana esteve desvalorizada relativamente à sua tendência secular, também ocorreu uma desvalorização do mil-réis, na esteira da Guerra do Paraguai. Dessa conjunção de crises independentes, de desvalorização de cada uma das moedas frente à libra, surgiu um movimento cíclico da taxa mil-réis por dólar, com quatro fases: a) uma depreciação forte do dólar relativamente ao mil-réis - 1861-64 -; b) uma depreciação do mil-réis relativamente ao dólar - 1864-70 -; c) nova depreciação, mais fraca, do dólar frente ao mil-réis - 1870-75-, num momento em que a valorização do mil-réis frente à libra foi maior do que a do dólar; e por fim d) uma desvalorização do mil-réis - 1875-79. Ao final desses dois ciclos, ambas as moedas retornavam à sua tendência secular por cerca de uma década. Os demais momentos de oscilações conjunturais mais fortes da taxa mil-réis por dólar, nesses cento e vinte anos, foram causados por eventos em somente um dos países.

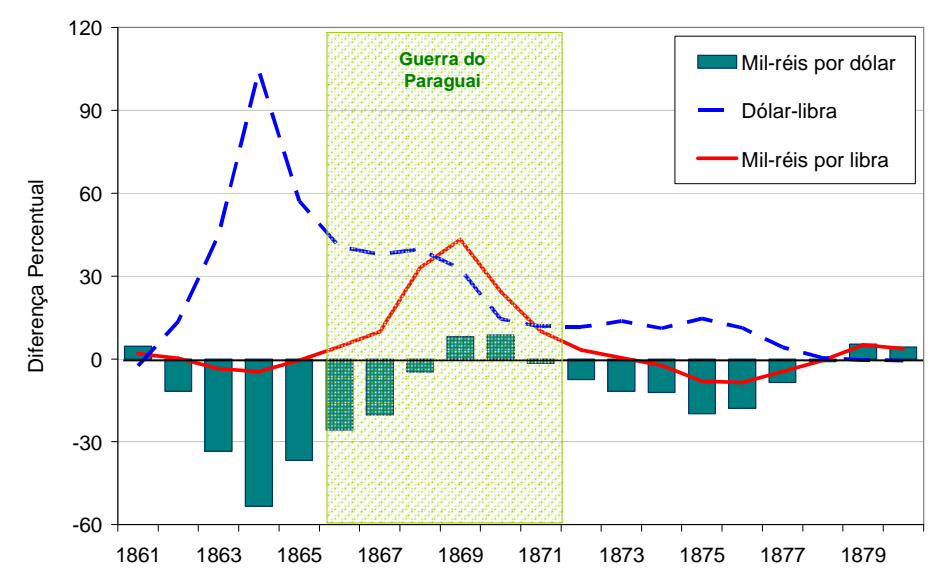

Gráfico 7: Afastamentos percentuais das taxas correntes com relação às taxas de longo prazo das 3 séries cambiais, em meados do século XIX Fonte: Séries dos quadros anteriores. 


\title{
A análise conjunta de curto e de longo prazo
}

Gostaríamos de realçar, através de um contra-exemplo, a vantagem da visão combinada de taxas correntes e taxas de longo prazo. Raymond Goldsmith, em seu ensaio macroeconômico sobre a história financeira do Brasil nos últimos cento e cinqüenta anos, afirma sobre a evolução do câmbio durante o Império:

\begin{abstract}
No entanto, o mil-réis desvalorizou-se em menos de $1 / 10$ entre o começo e o fim do período [entre 1850 e 1889], durante o qual o nível de preços brasileiros atingiu mais que o dobro, enquanto o de outros países decresceu ligeiramente. A relação pode constituir-se na combinação resultante, por um lado, de uma melhoria nas relações de troca do Brasil com a repetitiva escassez de cambiais por outro. (GOLDSMITH, 1986, p.62)
\end{abstract}

Ao usar, como taxa inicial para sua comparação, em 1850, um ponto coincidente entre taxas correntes e a curva de longo prazo, enquanto sua taxa final representava um pico de valorização cambial do mil-réis contra a libra, em 1889, Goldsmith deixa-se inadvertidamente levar pelas flutuações excepcionais, perdendo o rumo da tendência secular, o que mostramos na figura acima.

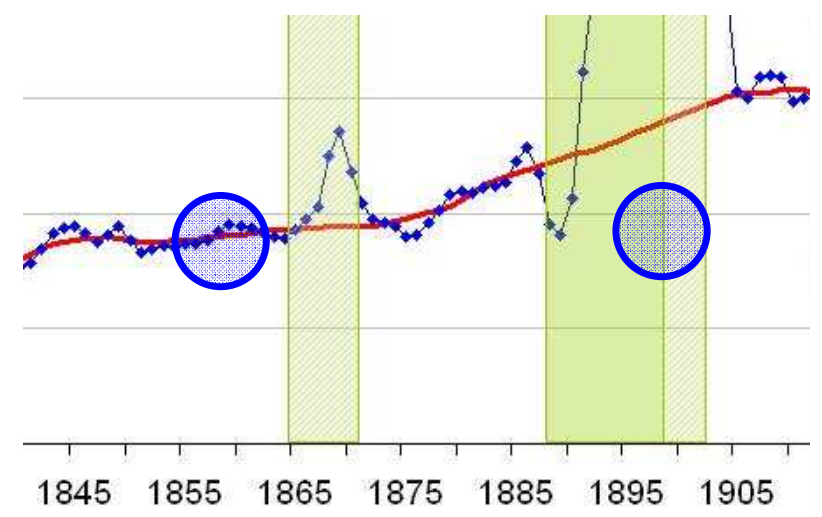

Figura 1: Detalhe do Gráfico 3 (Evolução da série mil-réis por libra) com indicação das taxas referenciadas por R.Goldsmith Fonte: Gráfico 3.

Fazendo uso das séries construídas aqui, os valores envolvidos são os seguintes:

\begin{tabular}{|c|c|c|}
\hline Ano & $\begin{array}{c}\text { Taxa } \\
\text { corrente }\end{array}$ & $\begin{array}{c}\text { Taxa de } \\
\text { longo prazo }\end{array}$ \\
\hline 1850 & 8,81 & 8,85 \\
\hline 1889 & 9,08 & 12,38 \\
\hline Variação & $3,1 \%$ & $39,9 \%$ \\
\hline
\end{tabular}


Seu raciocínio sobre a desvalorização do mil-réis acompanhou a variação das taxas correntes, de $3 \%$, enquanto a curva de longo prazo mostrava avanço bem superior, de $40 \%$. Talvez essa constatação não tivesse alterado completamente sua afirmação, mas sem dúvida teria dado a ela outro contexto, ao comparar uma inflação de $100 \%$ com uma depreciação cambial de $40 \%$ e não de $3 \% .^{14}$

No tocante às variações relativas do mil-réis e do dólar, fica claro que, apesar das oscilações cambiais de conjuntura, tanto o dólar frente à libra, quanto o mil-réis frente à moeda forte mundial, mantiveram suas próprias tendências de longo prazo. Na medida em que a tendência secular do dólar, após a independência do Brasil, foi extremamente estável, a tendência da série mil-réis por dólar seguiu de perto a curva de longo prazo do mil-réis frente à libra. Ao buscarmos comparações durante as décadas de 1860 e 1870, no entanto, é preciso atenção para os movimentos bilaterais do câmbio, que se descolaram das tendências de uma e outra moeda frente à libra.

Em segundo lugar, houve, em cada país, períodos marcantes de instabilidade cambial, inseridos em contextos mais amplos do que os meramente financeiros: guerras e graves agitações políticas. Cada um desses momentos tem sua própria história financeira e social, cuja compreensão poderá mostrar-se relevante para a análise comparativa, conforme o objeto específico de estudo. Assim, ao estudarmos a influência antecipada pela perspectiva de fim do tráfico negreiro sobre preços de escravos, os movimentos cíclicos de demanda por escravos nos setores exportadores ou os contextos regionais frente à conjuntura nacional, precisaremos entender melhor um ou outro desses momentos de oscilação conjuntural do câmbio ou, alternativamente, atentarmos para a dinâmica das oscilações diante da tendência secular.

Dependendo do interesse do historiador, a comparação de valores monetários poderá tornar-se mais relevante se empregada a série de longo prazo - caso trabalhe com escala temporal mais extensa - ou, ao contrário, exigirá o uso da série corrente anual, ou mesmo de taxas infra-anuais, para aferir os valores comparados numa escala de observação mais detalhada. Seja como for, qualquer comparação de preços ou custos, entre o Brasil e os Estados Unidos, deve combinar a periodização do tema específico abordado com aquela imposta pelas respectivas conjunturas e tendências cambiais entre

\footnotetext{
${ }^{14}$ A visão de que o câmbio, ao final do Império, estava supervalorizado foi expressa, na época, entre outros, por Rui Barbosa. Amaury Gremaud (2003, p.1) comenta: "Para Rui Barbosa (1892) a taxa de câmbio que a República herdou da Monarquia - de 27 dinheiros por mil-réis [=8,89 mil-réis por libra] era fictícia e sustentada pelo ingresso de capitais decorrente de empréstimos externos. Esta não poderia se sustentar naquele patamar por muito tempo. Foi justamente a instabilidade provocada pela mudança de regime e a saída de capital a causa da desvalorização cambial."
} 
o mil-réis e o dólar. Analogamente, outras comparações da economia brasileira, mediadas por transformações cambiais que utilizem a taxa mil-réis por libra, serão beneficiadas por uma análise que isole flutuações conjunturais da tendência de longo prazo do câmbio entre estas moedas.

\begin{abstract}
Three nominal exchange rate series are presented, for the mil-reis and the dollar in relation to sterling, and for the mil-reis in relation to the dollar. For each of these, two series are constructed: current rates and long-term rates, representing the secular tendency of these exchange rates. The main out-oftrend fluctuations of the mil-reis and the dollar are discussed, as well as the advantage of analyzing fluctuations and trend together. The text includes tables showing rates for all six series.
\end{abstract}

Key words: Exchange; Dollar, United States; Prices slaves.

\title{
Referências
}

AITKEN, H. G. J. (ed.) Did slavery pay? readings in the economics of black slavery in the United States. Boston: Houghton Mifflin, 1971. 343p.

BOTELHO JÚNIOR, C. D. O. "A crise cambial do encilhamento: algumas observações sobre a interpretação de Celso Furtado". Economia e Sociedade, v. 12, n. 2, p.275-294, 2003. Disponível em: http://www.eco.unicamp.br/publicacoes/economia_sociedade/ download/revista_21/07-Botelho.pdf.

CALÓGERAS, J. P. A política monetária do Brasil. São Paulo: Companhia Editora Nacional, 1960. 30p.

CARDOSO, C. F. S. Agricultura, escravidão e capitalismo. Petrópolis: Vozes, 1979.

DAVIS, L. E.; HUGHES, J. R. T. “A dollar-sterling exchange, 1803-1895”. Economic History Review, v. 13, n. 1, p.52-78, 1960.

DEGLER, C. N. Neither black nor white: slavery and race relations in Brazil and the United States. Madison: The University of Wisconsin Press, 1986.

DOAN, T. A.; DICK, T. J. O. Antebellum statistics. 2001. Disponível em: http://www. economics.utoronto.ca /floyd/dick.html.

DUNCAN, J. S. Public and private operation of railways in Brazil. New York: Columbia University Press, 1932. 243p.

FOGEL, R. W. The slavery debates 1952-1990: a retrospective. Baton Rouge: Louisiana State University Press, 2003. 106p. 
FRANCO, G. H. B. Setor externo. In: INSTITUTO BRASILEIRO DE GEOGRAFIA E ESTATÍSTICA. Estatísticas históricas do Brasil: séries econômicas, demográficas e sociais de 1550 a 1988. 2. ed. Rio de Janeiro: IBGE, 1990. p.557-599.

GOLDSMITH, R. W. Brasil 1850-1984: desenvolvimento financeiro sob um século de inflação. São Paulo: Harper \& Row do Brasil, 1986. 557p.

GRAHAM, R. "Purchasing power: a tentative approach and an appeal". Boletim de História Demográfica, v. 12, n. 36, p.19-24, 2005. Disponível em: http://historia_demografica.tripod.com /nec/bhd36.pdf.

GRAHAM, R. "Slavery and economic development: Brazil and the United States South in the Nineteenth Century". Comparative Studies in Society and History, v. 23, n. 4, p.620-655, 1981.

GREMAUD, A. P. A política econômica na passagem do século XIX para o XX: controvérsias em torno da questão monetária. V CONGRESSO BRASILEIRO DE HISTÓRIA ECONÔMICA, 5; $6^{\mathrm{a}}$ CONFERÊNCIA INTERNACIONAL DE HISTÓRIA DE EMPRESAS, 6, 2003, Caxambu, MG. Anais... Caxambu: ABPHE, 2003. p.17. Disponível em: http://www.abphe.org.br/congresso2003/textos/Abphe _2003_108.pdf.

GUIMARÃES, C. G. O Império e os bancos comerciais do Rio de Janeiro na segunda metade do século XIX: os casos do Banco Mauá, MacGregor \& Cia, do Banco Rural e Hipotecário do Rio de Janeiro e do Banco Comercial e Agrícola. In: CONGRESSO BRASILEIRO DE HISTÓRIA ECONÔMICA, 3; CONFERÊNCIA INTERNACIONAL DE HISTÓRIA DE EMPRESAS, 4, 1999,Curitiba. Anais... Curitiba: Associação Brasileira de Pesquisadores em História Econômica, 1999. Disponível em: http://www. abphe.org.br/congresso1999/Textos/CARL_4B.pdf.

GUIMARÃES, C. G. A Guerra do Paraguai e a atividade bancária no Rio de Janeiro no período 1865-1870: o caso Banco Rural e Hipotecário do Rio de Janeiro. Universidade Federal Fluminense, 2007. Disponível em: http://www.historia.uff.br/artig.php.

GUIMARÃES, C. G. A atuação do London and Brazilian Bank no Brasil e em Portugal (filiais de Lisboa e do Porto) no período 1862-1870. In: ENCONTRO DA ASSOCIAÇÃO PORTUGUESA DE HISTÓRIA ECONÓMICA E SOCIAL, 29, 2009, Porto. Anais... Porto: APHES, 2009. Disponível em: http://web.letras.up.pt/aphes29/data/7th/Carlos Guimar\%C3\%A3es_Texto.pdf.

INSTITUTO BRASILEIRO DE GEOGRAFIA E ESTATÍSTICA. Estatísticas históricas do Brasil: séries econômicas, demográficas e sociais de 1550 a 1988. 2. ed. Rio de Janeiro: IBGE, 1990. 642p.

KLOVLAND, J. T. Historical exchange rate data 1819-2003. In: KLOVLAND, J. T. Historical monetary statistics for Norway from 1819. Oslo: Norges Bank, 2004. p.289327. Disponível em: http://www.norges-bank.no/stat/historiske_data/en/hms/c7.pdf. 
LAGO, L. A. C. D. The transition from slave to free labor in agriculture in the southern and coffee regions of Brazil: a global and theoretical approach and regional case studies. (Tese Doutorado) - Harvard University, Department of Economics, Cambridge, 1978.

LEVY, M. B. História da Bolsa de Valores do Rio de Janeiro. Rio de Janeiro: IBMEC, 1977. 660p.

MACDONALD, R.; TAYLOR, M. P. "Exchange rate economics: a survey". Staff Papers: International Monetary Fund, v. 39, n. 1, p.1-57, 1992.

MELLO, P. C. D. The economics of labor in brazilian coffee plantation: 1850-1888. (Tese Doutorado) - University of Chicago, Department of Economics, Chicago, 1977.

MELLO, P. C. D.; SLENES, R. W. Análise econômica da escravidão o Brasil. In: NEUHAUS, P. C. Economia brasileira: uma visão histórica. Rio de Janeiro: Campus, 1980. p.89-122.

MITCHENER, K. J.; WEIDENMIER, M. D. The baring crisis and the Great Latin American meltdown of the 1890s. 2006. Disponível em: http://www.econ.berkeley.edu I webfac/eichengreen/e211_fa06/Mitchener.pdf.

NORMANO, J. F. Evolução econômica do Brasil. 2. ed. São Paulo: Companhia Editora Nacional, 1975. 216p.

NOZOE, N. et al. "Brasil: breves comentários sobre algumas séries referentes à taxa de câmbio". Boletim de História Demográfica, n. 32, p.15-18, 2004. Disponível em: http://members.tripod.com/ Historia_Demografica/bhds/bhd32/cambio.pdf.

OFFICER, L. H. Information on European exchange rates. 2002. Disponível em: http://eh.net/hmit/exchangerates/infoeurope.htm.

SCHWARTZ, S. B. Sugar plantations in the formation of brazilian society. Cambridge: Cambridge University Press, 1985.

SIMONSEN, R. C. História econômica do Brasil (1500/1820). 6. ed. São Paulo: Companhia Editora Nacional, 1969. 475p.

SLENES, R. W. The demography and economics of brazilian slavery: 1850-1888. (Tese Doutorado) Stanford University, Department of History: Stanford, 1976.

THORTON, M. "Slavery, profitability, and the market process". The Review of Austrian Economics, v. 7, n. 2, p.21-47, 1994. Disponível em: <http://www.mises.org/ journals/ rae/pdf/rae7_2_2.pdf.

TRINER, G. International capital and the brazilian encilhamento, 1889-1891: an early example of contagion among emerging capital markets? 2001. Disponível em: http:// www-histecon.kings.cam.ac.uk/docs/contagion_triner.pdf. 
VERSIANI, F. R. "Brazilian slavery: toward an economic analysis". Tradução de Fábio S. de Oliveira. Revista Brasileira de Economia, v. 48, n. 4, p.463-478, 1994. Disponível em: http://www.unb.br/face/eco/bmueller/escravidao.pdf.

VILLELA, A. Tempos difíceis: reações às crises de 1857 e 1864 no Brasil. In: CONGRESSO BRASILEIRO DE HISTÓRIA ECONÔMICA, 3; CONFERENCIA INTERNACIONAL DE HISTÓRIA DE EMPRESAS, 4, 1999, Curitiba. Anais... Curitiba: Associação Brasileira de Pesquisadores em História Econômica, 1999. p.23. Disponível em: http://www.abphe.org.br/congresso1999/Textos/ANDRE.pdf.

VILLENEUVE, J. Retrospecto Commercial de [1876-1932]. Jornal do Commercio, Rio de Janeiro. 1876-1932. Disponível em: http://memoria.nemesis.org.br/index.php? $\mathrm{p}=3 \& \mathrm{~b}=0$ 
ANEXO - SÉRIES CAMBIAIS (1)

1795 - 1824

\begin{tabular}{|c|c|c|c|c|c|c|}
\hline & \multicolumn{2}{|c|}{ Mil-réis por libra } & \multicolumn{2}{|c|}{ Dólares por libra } & \multicolumn{2}{|c|}{ Mil-réis por dólar } \\
\hline & Corrente & $\begin{array}{l}\text { Longo } \\
\text { prazo }\end{array}$ & Corrente & $\begin{array}{l}\text { Longo } \\
\text { prazo }\end{array}$ & Corrente & $\begin{array}{l}\text { Longo } \\
\text { prazo }\end{array}$ \\
\hline & 1 & 2 & 3 & 5 & 6 & 7 \\
\hline 1795 & 3,56 & 3,56 & 4,53 & 4,53 & 0,78 & 0,78 \\
\hline 1796 & 3,56 & 3,56 & 4,29 & 4,44 & 0,83 & 0,80 \\
\hline 1797 & 3,56 & 3,56 & 4,44 & 4,42 & 0,80 & 0,80 \\
\hline 1798 & 3,56 & 3,56 & 4,39 & 4,42 & 0,81 & 0,80 \\
\hline 1799 & 3,56 & 3,56 & 4,13 & 4,42 & 0,86 & 0,80 \\
\hline 1800 & 3,56 & 3,56 & 4,55 & 4,43 & 0,78 & 0,80 \\
\hline 1801 & 3,56 & 3,56 & 4,38 & 4,42 & 0,81 & 0,80 \\
\hline 1802 & 3,56 & 3,56 & 4,49 & 4,41 & 0,79 & 0,81 \\
\hline 1803 & 3,56 & 3,54 & 4,54 & 4,40 & 0,78 & 0,80 \\
\hline 1804 & 3,56 & 3,52 & 4,55 & 4,39 & 0,78 & 0,80 \\
\hline 1805 & 3,56 & 3,50 & 4,35 & 4,38 & 0,82 & 0,80 \\
\hline 1806 & 3,56 & 3,48 & 4,43 & 4,37 & 0,80 & 0,80 \\
\hline 1807 & 3,56 & 3,45 & 4,42 & 4,37 & 0,80 & 0,79 \\
\hline 1808 & 3,43 & 3,41 & 4,63 & 4,36 & 0,74 & 0,78 \\
\hline 1809 & 3,33 & 3,34 & 4,57 & 4,36 & 0,73 & 0,77 \\
\hline 1810 & 3,29 & 3,31 & 4,30 & 4,35 & 0,76 & 0,76 \\
\hline 1811 & 3,36 & 3,36 & 3,82 & 4,34 & 0,88 & 0,77 \\
\hline 1812 & 3,24 & 3,39 & 3,62 & 4,35 & 0,90 & 0,78 \\
\hline 1813 & 3,09 & 3,37 & 3,75 & 4,38 & 0,82 & 0,77 \\
\hline 1814 & 2,73 & 3,39 & 4,24 & 4,42 & 0,64 & 0,77 \\
\hline 1815 & 3,23 & 3,46 & 4,90 & 4,47 & 0,66 & 0,78 \\
\hline 1816 & 4,16 & 3,59 & 5,22 & 4,52 & 0,80 & 0,80 \\
\hline 1817 & 3,84 & 3,73 & 4,60 & 4,56 & 0,83 & 0,82 \\
\hline 1818 & 3,36 & 3,87 & 4,50 & 4,60 & 0,75 & 0,84 \\
\hline 1819 & 3,64 & 4,04 & 4,51 & 4,64 & 0,81 & 0,87 \\
\hline 1820 & 4,19 & 4,22 & 4,52 & 4,68 & 0,93 & 0,90 \\
\hline 1821 & 4,71 & 4,38 & 4,82 & 4,72 & 0,98 & 0,93 \\
\hline 1822 & 4,90 & 4,48 & 4,98 & 4,75 & 0,98 & 0,94 \\
\hline 1823 & 4,74 & 4,64 & 4,80 & 4,78 & 0,99 & 0,97 \\
\hline 1824 & 4,98 & 4,87 & 4,87 & 4,79 & 1,02 & 1,02 \\
\hline
\end{tabular}




$$
\begin{gathered}
\text { ANEXO - SÉRIES CAMBIAIS (2) } \\
1825-1854
\end{gathered}
$$

\begin{tabular}{|c|c|c|c|c|c|c|}
\hline & \multicolumn{2}{|c|}{ Mil-réis por libra } & \multicolumn{2}{|c|}{ Dólares por libra } & \multicolumn{2}{|c|}{ Mil-réis por dólar } \\
\hline & Corrente & $\begin{array}{l}\text { Longo } \\
\text { prazo }\end{array}$ & Corrente & $\begin{array}{l}\text { Longo } \\
\text { prazo }\end{array}$ & Corrente & $\begin{array}{l}\text { Longo } \\
\text { prazo }\end{array}$ \\
\hline & 1 & 2 & 3 & 5 & 6 & 7 \\
\hline 1825 & 4,63 & 5,10 & 4,83 & 4,80 & 0,96 & 1,06 \\
\hline 1826 & 5,00 & 5,31 & 4,92 & 4,81 & 1,02 & 1,11 \\
\hline 1827 & 6,80 & 5,51 & 4,94 & 4,80 & 1,38 & 1,15 \\
\hline 1828 & 7,75 & 5,64 & 4,93 & 4,80 & 1,57 & 1,17 \\
\hline 1829 & 9,71 & 5,79 & 4,86 & 4,80 & 2,00 & 1,20 \\
\hline 1830 & 10,49 & 5,89 & 4,76 & 4,81 & 2,20 & 1,23 \\
\hline 1831 & 9,62 & 6,03 & 4,86 & 4,82 & 1,98 & 1,25 \\
\hline 1832 & 6,80 & 6,23 & 4,86 & 4,85 & 1,40 & 1,28 \\
\hline 1833 & 6,42 & 6,51 & 4,79 & 4,86 & 1,34 & 1,34 \\
\hline 1834 & 6,31 & 6,73 & 4,64 & 4,88 & 1,36 & 1,38 \\
\hline 1835 & 6,15 & 6,89 & 4,85 & 4,90 & 1,27 & 1,41 \\
\hline 1836 & 6,18 & 7,04 & 4,82 & 4,92 & 1,28 & 1,43 \\
\hline 1837 & 7,18 & 7,22 & 5,10 & 4,92 & 1,41 & 1,47 \\
\hline 1838 & 8,34 & 7,43 & 4,89 & 4,93 & 1,70 & 1,51 \\
\hline 1839 & 8,07 & 7,70 & 4,99 & 4,93 & 1,62 & 1,56 \\
\hline 1840 & 7,67 & 7,99 & 5,00 & 4,93 & 1,53 & 1,62 \\
\hline 1841 & 7,83 & 8,26 & 4,99 & 4,93 & 1,57 & 1,68 \\
\hline 1842 & 8,44 & 8,50 & 4,80 & 4,93 & 1,76 & 1,72 \\
\hline 1843 & 9,13 & 8,67 & 4,79 & 4,91 & 1,91 & 1,77 \\
\hline 1844 & 9,41 & 8,77 & 4,86 & 4,90 & 1,94 & 1,79 \\
\hline 1845 & 9,48 & 8,84 & 4,87 & 4,89 & 1,95 & 1,81 \\
\hline 1846 & 9,17 & 8,89 & 4,82 & 4,88 & 1,90 & 1,82 \\
\hline 1847 & 8,74 & 8,95 & 4,79 & 4,87 & 1,82 & 1,84 \\
\hline 1848 & 9,08 & 8,97 & 4,87 & 4,88 & 1,87 & 1,84 \\
\hline 1849 & 9,44 & 8,92 & 4,81 & 4,89 & 1,96 & 1,82 \\
\hline 1850 & 8,81 & 8,85 & 4,87 & 4,89 & 1,81 & 1,81 \\
\hline 1851 & 8,30 & 8,78 & 4,91 & 4,90 & 1,69 & 1,79 \\
\hline 1852 & 8,50 & 8,75 & 4,90 & 4,90 & 1,73 & 1,79 \\
\hline 1853 & 8,59 & 8,80 & 4,89 & 4,91 & 1,76 & 1,79 \\
\hline 1854 & 8,56 & 8,83 & 4,88 & 4,90 & 1,75 & 1,80 \\
\hline
\end{tabular}


ANEXO - SÉRIES CAMBIAIS (3)

1855 - 1884

\begin{tabular}{|c|c|c|c|c|c|c|}
\hline & \multicolumn{2}{|c|}{ Mil-réis por libra } & \multicolumn{2}{|c|}{ Dólares por libra } & \multicolumn{2}{|c|}{ Mil-réis por dólar } \\
\hline & Corrente & $\begin{array}{l}\text { Longo } \\
\text { prazo }\end{array}$ & Corrente & $\begin{array}{l}\text { Longo } \\
\text { prazo }\end{array}$ & Corrente & $\begin{array}{l}\text { Longo } \\
\text { prazo }\end{array}$ \\
\hline & 1 & 2 & 3 & 5 & 6 & 7 \\
\hline 1855 & 8,70 & 8,83 & 4,89 & 4,90 & 1,78 & 1,80 \\
\hline 1856 & 8,71 & 8,88 & 4,91 & 4,90 & 1,77 & 1,81 \\
\hline 1857 & 8,87 & 8,97 & 4,89 & 4,90 & 1,81 & 1,83 \\
\hline 1858 & 9,22 & 9,01 & 4,86 & 4,90 & 1,90 & 1,84 \\
\hline 1859 & 9,49 & 9,04 & 4,90 & 4,90 & 1,94 & 1,85 \\
\hline 1860 & 9,44 & 9,11 & 4,85 & 4,90 & 1,95 & 1,86 \\
\hline 1861 & 9,35 & 9,17 & 4,77 & 4,89 & 1,96 & 1,87 \\
\hline 1862 & 9,26 & 9,23 & 5,56 & 4,89 & 1,67 & 1,89 \\
\hline 1863 & 8,97 & 9,29 & 7,08 & 4,89 & 1,27 & 1,90 \\
\hline 1864 & 8,89 & 9,32 & 10,00 & 4,89 & 0,89 & 1,90 \\
\hline 1865 & 9,28 & 9,33 & 7,69 & 4,89 & 1,21 & 1,91 \\
\hline 1866 & 9,78 & 9,36 & 6,88 & 4,89 & 1,42 & 1,91 \\
\hline 1867 & 10,33 & 9,40 & 6,75 & 4,90 & 1,53 & 1,92 \\
\hline 1868 & 12,54 & 9,43 & 6,83 & 4,89 & 1,84 & 1,93 \\
\hline 1869 & 13,57 & 9,47 & 6,48 & 4,89 & 2,09 & 1,94 \\
\hline 1870 & 11,79 & 9,48 & 5,59 & 4,88 & 2,11 & 1,94 \\
\hline 1871 & 10,41 & 9,46 & 5,46 & 4,89 & 1,91 & 1,94 \\
\hline 1872 & 9,79 & 9,48 & 5,45 & 4,88 & 1,80 & 1,94 \\
\hline 1873 & 9,59 & 9,55 & 5,55 & 4,88 & 1,73 & 1,96 \\
\hline 1874 & 9,44 & 9,67 & 5,42 & 4,88 & 1,74 & 1,98 \\
\hline 1875 & 9,00 & 9,80 & 5,59 & 4,88 & 1,61 & 2,01 \\
\hline 1876 & 9,06 & 9,91 & 5,42 & 4,87 & 1,67 & 2,03 \\
\hline 1877 & 9,58 & 10,04 & 5,08 & 4,87 & 1,89 & 2,06 \\
\hline 1878 & 10,12 & 10,17 & 4,89 & 4,87 & 2,07 & 2,09 \\
\hline 1879 & 10,85 & 10,33 & 4,85 & 4,87 & 2,24 & 2,12 \\
\hline 1880 & 10,98 & 10,59 & 4,84 & 4,87 & 2,27 & 2,18 \\
\hline 1881 & 10,87 & 10,94 & 4,83 & 4,87 & 2,25 & 2,25 \\
\hline 1882 & 11,15 & 11,19 & 4,87 & 4,86 & 2,29 & 2,30 \\
\hline 1883 & 11,24 & 11,41 & 4,85 & 4,86 & 2,32 & 2,35 \\
\hline 1884 & 11,37 & 11,59 & 4,85 & 4,86 & 2,34 & 2,38 \\
\hline
\end{tabular}


ANEXO - SÉRIES CAMBIAIS (4)

1885 - 1913

\begin{tabular}{|c|c|c|c|c|c|c|}
\hline & \multicolumn{2}{|c|}{ Mil-réis por libra } & \multicolumn{2}{|c|}{ Dólares por libra } & \multicolumn{2}{|c|}{ Mil-réis por dólar } \\
\hline & Corrente & $\begin{array}{l}\text { Longo } \\
\text { prazo }\end{array}$ & Corrente & $\begin{array}{l}\text { Longo } \\
\text { prazo }\end{array}$ & Corrente & $\begin{array}{l}\text { Longo } \\
\text { prazo }\end{array}$ \\
\hline & 1 & 2 & 3 & 5 & 6 & 7 \\
\hline 1885 & 12,26 & 11,73 & 4,86 & 4,86 & 2,52 & 2,41 \\
\hline 1886 & 12,89 & 11,87 & 4,86 & 4,86 & 2,65 & 2,44 \\
\hline 1887 & 11,78 & 12,05 & 4,85 & 4,87 & 2,43 & 2,47 \\
\hline 1888 & 9,51 & 12,21 & 4,87 & 4,87 & 1,95 & 2,51 \\
\hline 1889 & 9,08 & 12,38 & 4,87 & 4,87 & 1,86 & 2,54 \\
\hline 1890 & 10,64 & 12,56 & 4,86 & 4,87 & 2,19 & 2,58 \\
\hline 1891 & 16,18 & 12,68 & 4,86 & 4,87 & 3,33 & 2,60 \\
\hline 1892 & 20,04 & 12,76 & 4,87 & 4,87 & 4,11 & 2,62 \\
\hline 1893 & 20,83 & 12,95 & 4,86 & 4,87 & 4,29 & 2,66 \\
\hline 1894 & 23,92 & 13,15 & 4,88 & 4,87 & 4,90 & 2,70 \\
\hline 1895 & 24,27 & 13,35 & 4,89 & 4,87 & 4,96 & 2,74 \\
\hline 1896 & 26,67 & 13,54 & 4,87 & 4,87 & 5,48 & 2,78 \\
\hline 1897 & 31,85 & 13,74 & 4,86 & 4,87 & 6,55 & 2,82 \\
\hline 1898 & 33,67 & 13,94 & 4,85 & 4,87 & 6,94 & 2,86 \\
\hline 1899 & 32,57 & 14,13 & 4,86 & 4,87 & 6,70 & 2,90 \\
\hline 1900 & 25,64 & 14,33 & 4,87 & 4,87 & 5,27 & 2,94 \\
\hline 1901 & 21,12 & 14,49 & 4,87 & 4,87 & 4,34 & 2,98 \\
\hline 1902 & 20,21 & 14,70 & 4,87 & 4,87 & 4,15 & 3,02 \\
\hline 1903 & 20,14 & 14,90 & 4,86 & 4,87 & 4,14 & 3,06 \\
\hline 1904 & 19,72 & 15,09 & 4,87 & 4,87 & 4,05 & 3,10 \\
\hline 1905 & 15,31 & 15,16 & 4,87 & 4,87 & 3,14 & 3,11 \\
\hline 1906 & 15,06 & 15,22 & 4,85 & 4,87 & 3,10 & 3,13 \\
\hline 1907 & 15,90 & 15,26 & 4,86 & 4,87 & 3,27 & 3,14 \\
\hline 1908 & 15,98 & 15,29 & 4,87 & 4,87 & 3,28 & 3,14 \\
\hline 1909 & 15,96 & 15,39 & 4,87 & 4,87 & 3,28 & 3,16 \\
\hline 1910 & 14,90 & 15,43 & 4,86 & 4,87 & 3,07 & 3,17 \\
\hline 1911 & 15,02 & 15,41 & 4,86 & 4,87 & 3,09 & 3,17 \\
\hline 1912 & 15,00 & 15,19 & 4,87 & 4,87 & 3,08 & 3,12 \\
\hline 1913 & 15,00 & 15,34 & 4,87 & 4,87 & 3,08 & 3,15 \\
\hline 1914 & 16,01 & & 4,93 & & 3,25 & \\
\hline
\end{tabular}

